\title{
REFERENCES
}

1. Статистичний щорічник Украйни, 2014 рік [Текст] : статистичний щчорічник / Державна служба статистики Украӥни / О. А. Вишневська (від. За вип). - К.: Держаналітінформ., 2015. - 585 c.

2. Wang, Q.; Kuninobu, M.; Ogawa, H.; Kato, Y. Degradation of volatile fatty acids in highly efficient anaerobic digestion. Biomass Bioenergy 1999, 16, pp. 407-416.

3. Rajeshwari K.V., Balakrishnan M., Kansal A., Kusum Lata and Kishore V.V.N., State-of-the-art of Anaerobic Digestion Technology for Industrial Wastewater Treatment, Renewable and Sustainable Energy Reviews, 2000, Vol. 4, pp. 135-156.

4. V. ReginattoI, R. M. TeixeiraI; F. PereiraI; W. SchmidellI; A. Furigo JrI; R. MenesII; C. EtchebehereII; H. M. Soares Anaerobic ammonium oxidation in a bioreactor treating slaughterhouse wastewater, Brazilian Journal of Chemical Engineering 2005, vol.22 no.4, http://dx.doi.org/10.1590/S0104-66322005000400012.

5. Viet N.T. Sustainable Treatment of Rubber Latex Processing Wastewater-the UASB-System Combined with Aerobic PostTreatment, Thesis, The Wageningen University, Wageningen, The Netherlands, 1999) pp. 1-17.

6. Malashenko Y.R. Medium redox-potential during cultivation of mehtanogenic community / J.R. Malashenko, D.V. Chernyshenko, Y.N. Danko, L.S. Yastremskaya, V.I Karpenko: Symposium on biotechnology for fuel and chemicals (8-12 may 1989): Abstr. - Colorado-Spring. - USA. - 1989. - P.82.

7. Sharon McHugh, Micheal Carton, There'se Mahony, Vincent O'Flaherty Methanogenic population structure in a variety of anaerobic bioreactors; FEMS Microbiology Letters 219 (2003) 297^304 doi:10.1016/S0378-1097(03)00055-7.

Надійшла 23.01.2016. До друку 13.02.2016

Адреса для переписки:

вул. Канатна, 112, м. Одеса, 65039

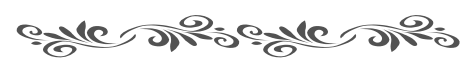

УДК 664.785

С.М. СОЦ, канд. техн. наук., доцент, В.Т. ГУЛАВСЬКИЙ, канд. техн. наук., I.О. КУСТОВ, канд. техн. наук., асистент

\section{БОРОШНО ТА ВИСІВКИ - НОВІ ПРОДУКТИ ІЗ ГОЛОЗЕРНОГО ВIВСА}

\begin{abstract}
Анотація
Аналіз існуючих в Україні традиційних технологій переробки зернових і бобових культур в крупи і круп'яні продукти показує, що на сьогоднішній день переважна більшість діючих технологій була розроблена 20-30 років тому і передбачає використання значної кількості систем і операчій, особливо лущення та шліфування при реалізачії яких передбачається застосування машин типу ЗШН, що у сукупності передбачає значну енергоємність прочесу. При иьому асортимент круп'яної продукиії, що виробляється більшою мірою залишається стабільним і включає крупи подрібнені та неподрібнені, пластівиі та борошно. У більшості сучасно орієнтованих країн протягом останніх років відбувається перехід до нових скорочених і більш енергоефективних технологій переробки зернових культур в крупи та круп'яні продукти при цьому відбувається також впровадження нових високопродуктивних сортів зернових культур. Особливе місие при иьому займають голозерні форми традиційних культур - вівса та ячменю. На основі иієї сировини відбувається розиирення асортименту, збільшення виходу готової продукиії, підвищення їі харчової иінності. В нашій країні вітчизняними селекціонерами також отримані високопродуктивні сорти традиційних круп'яних культур, однак необхідно звернути увагу на те, щзо, наприклад, нові сорти пшеничі переважною мірою за анатомічною і морфологічною будовою є аналогічними $і$ їх переробка не потребує суттєвої перебудови технологічного процесу, але такі культури як голозерний овес чи голозерний ячмінь переробляти відповідно до існуючих режимів і структури складно, ие призводить до неповного використання потенціалу переробляємої сировини та нівелює усі ї̈ переваги над традииійною. Враховуючи це актуальною проблемою для вітчизняного круп'яного виробництва є розробка нових енергоефективних технологій, розширення існуючого асортименту продуктів та підвищення ї̈ харчової чінності. В одеській національній академії харчових технологій на кафедрі технології переробки зерна проводяться дослідження метою яких є розробка науково обтрунтованих технологій переробки нових видів зернової сировини і ї̈ впровадження у вітчизняне круп'яне виробничтво. У даній статті наведено структуру та основні етапи переробки голозерного вівса в круп'яні продукти. Наведено основні відмінності застосування голозерного вівса як сировини для виробництва круп'яних продуктів в порівнянні із плівковими формами круп'яного вівса. Проаналізовано можливості використання голозерного вівса для розширення асортименту вівсяних продуктів за рахунок виробництва круп пропарених, не пропарених, круп плющених, пластівців та борощна. При изьому прочес виробництва розглянутої продукції характеризується скороченою структурою технологічного процесу, продукти в порівнянні із класичними мають підвищений вихід та якість.

Ключові слова: крупа вівсяна, воднотеплова обробка, очищення зерна від домішок, пропарювання, плющені продукти, вівсяне борочно, голозерний овес, скорочена структура технологічного процесу, підвищення харчової цінності.
\end{abstract}

Продукти переробки вівса в Україні за останні десятиліття стали традиційними для більшості населення нашої країни. Основою високого попиту на вівсяну продукцію є висока харчова цінність, яка формується за рахунок високого вмісту білка, повноцінності амінокислотного складу, наявності високого вмісту жирів та ненасичених жирних кислот, вмісту харчових волокон, особливо $\beta$-глюканів, вітамінів т.д
Відповідно до Правил ведення і організації технологічного процесу на круп'яних заводах овес переробляють в крупи неподрібнені, плющені, пластівці «Геркулес», «Пелюсткові», «Екстра». Сировиною для виробництва зазначеного асортименту круп та круп'яних продуктів є зерно плівчастого вівса продовольчих потреб, I-III клас відповідно до ДСТУ 49632008. Особливістю зазначених сортів вівса $є$ висока 
плівчастість, яка може досягати 40 \%. Тому виробництво існуючого асортименту вівсяних продуктів $\epsilon$ ускладненим, включає енергоємні етапи воднотеплової обробки, лущення, сортування продуктів лущення, круповідділення, повторне лущення, шліфування, сортування продуктів шліфування, що проводять для того щоб отримати ядро вівса яке відносять до круп неподрібнених. При подальшому використанні крупи неподрібненої для виробництва пластівців технологічний процес також включає невід'ємні операції з контролю крупи на двох системах падді-машин та крупосортувальній системі. При виробництві пластівців «Пелюсткові» застосовують додатковий етап шліфування ядра та його сортування.

Окремими продуктами переробки вівса $є$ толокно та різні види вівсяного борошно. Даний продукт завдяки відсутністю клейковини як самостійний майже не застосовується, однак у сумішах із пшеничним борошном його широко застосовують у хлібопекарській промисловості при виробництві хліба, хлібобулочних та кондитерських виробів та в якості поліпшувача в інших галузях харчової та переробної промисловості. На вітчизняних круп'яних заводах передбачено виробництво толокна (відповідно до «Правил...»), а також двох основних видів вівсяного борошна: «сортового» та «обивного».

Переробка вівса в толокно регламентована діючими «Правилами...» ї включає очищення зерна від домішок, видалення щуплого і недозрілого зерна, замочування, варіння, сушіння, охолодження, лущення, сортування продуктів лущення у три етапи, повторне лущення, здрібнювання та сортування продуктів здрібнювання. Зерно вівса очищують від домішок, видаляють щупле і недозріле зерно та замочують у підігрітій до $35^{\circ} \mathrm{C}$ воді протягом двох годин. Після цього зерно варять протягом 1,5-2,0 годин при тиску пари 0,15-0,20 МПа та сушать вологості 5-6 \%. Після охолодження зерно надходить на лущення. Даний етап здійснюють лущильному посаді або у відцентровому лущильнику. Сортування продуктів лущення здійснюють у центрофугалі де проходом сита Ø 2,0 мм вилучають борошенце та частинки подрібненого ядра, після чого, в повітряному сепаратоpi, вилучають лузгу. Суміш лущеного і нелущеного зерна надходить на етап круповідділення, який здійснюється у падді-машині. Нелущене зерно повертають на лущильну систему, ядро - після додаткового контролю у повітряному сепараторі надходить на здрібнювання. Етап здрібнювання здійснюють на двох системах вальцьових верстатів. Сортування продуктів здрібнювання проводять після кожної системи здрібнювання. Для сортування використовують круп'яні розсійники. Борошно відбирають на кожній сортувальній системі проходом шовкових сит № $27 \mathrm{i}$ № 29 або поліамідних сит № 27 ПА-120 і № 29 ПА120 та направляють на контроль. Враховуючи таку складність технологічного процесу, необхідність довготривалого замочування зерна, використання варильних апаратів, сушіння тощо дана технологія на території України не знайшла застосування. Більш розповсюдженими технологіями переробки вівса в борошно є менш складні технології відповідно до яких на першому етапі отримують крупу неподрібнену (лущене ядро), яке після додаткової обробки (плющення, різання тощо) здрібнюють у борошно.

Однак незважаючи на меншу в порівнянні із виробництвом толокна складність дані технології також передбачають енергоємні етапи воднотеплової обробки зерна (пропарювання зерна при надлишковому тиску в пропарювачах), його лущення (як правило на двох системах), необхідність сортування продуктів лущення з наступним круповідділення (для вилучення нелущеного зерна яке спрямовують на другу лущильну систему), що потребує значних виробничих площ для розміщення відповідних машин та труднощі у здійсненні даного процесу на заводах iз невеликою кількістю виробничих площ.

В нашій країні майже відсутній такий важливий продукт як вівсяні харчові висівки які традиційно отримують при здрібнюванні вівсяного зерна. Основною метою при виробництві усіх видів борошна в нашій країні є отримання максимального виходу подрібненого продукту, тому, як правило, висівки, що отримують після здрібнювання не використовується як цінний харчовий продукт. В країнах ЕС, Америки, особливо США вівсяні висівки з останньої чверті XX ст. увійшли в асортимент найбільш корисних і дієтичних продуктів. Їх особливістю $є$ високий рівень харчових волокон (до $16 \%$ ) особливо корисних для організму людини $\beta$-глюканів $(5,5-23,0 \%)$, високий вміст білка (4-8 \%) та відповідно збагачений амінокислотний склад тощо.

Сьогодні у світі відбувається перехід до менш складних та більш енергоефективних технологій, що при переробленні нових сортів зернових культур, наприклад голозерного вівса дозволяє отримувати зернові продукти зі збільшеним виходом та покращеною харчовою цінністю. К. Sерро та інші розробили технологію для виробництва продукту збагаченого $\beta$-глюканами яка передбачає використання голозерного вівса (або лущеного ядра вівса). Продукт являє собою тонко здрібнену фракцію вівсяного борошна i може використовуватися у зернових сніданках, готових до споживання продуктах тощо. Технологічний процес виробництва передбачає подрібнення вівсяного зерна на двох системах, після кожного здрібнювання передбачена своя сортувальна система. Перша сортувальна система забезпечує розділення продуктів здрібнювання на дві фракції: грубу (вміщує оболонкові частини) та попередньо збагачену більш тонку фракцію (вміщує частини ендосперму разом із субалейроновим шаром), яку направляють на повторне здрібнювання. Друга сортувальна система забезпечує розділення продуктів здрібнювання на дві фракції, за винятком того, що отримана на цьому етапі груба фракція являє собою готовий продукт.

В Україні зерно голозерного вівса не зважаючи на його наявність в нашій країні протягом 10-15 років не використовується для виробництва харчових продуктів. Це пов'язано в першу чергу з відсутністю регламенту а також тим що здійснення переробки даного сорту вівса за існуючими технологіями, навіть при очевидному виключенні із технологічного процесу певних операцій не призводить до бажаного ефекти. Існуючі рекомендації не враховують особливостей технологічних властивостей, особливостей 
наявності необрушеного і плівчастого зерна в суміші 3 голозерним а також хімічного складу. Все це призводить до того що надзвичайно високу за своїм круп'яним потенціалом культури переробляють в крупи та круп'яні продукти які за своїми якісними властивостями не відповідають регламентованим нормам, або навпаки виробляється регламентована продукція але така, що має майже аналогічний із традиційними вівсяними продуктами вихід. У таких умовах вітчизняні переробні підприємства не готові приймати на переробку зерно голозерного вівса, що в свою чергу призводить вже до зменшення обсягів вирощування даної культури.

На кафедрі технології переробки зерна Одеської національної академії харчових технологій проводяться дослідження голозерних сортів вівса, метою яких є підвищення ефективності переробки вівса у напрямку збільшення виходу готових продуктів та розширення існуючого асортименту круп і круп'яних продуктів різного призначення. Метою даного дослідження є розробка структури та етапів технологічного процесу переробки зерна голозерного вівса в борошно, що дозволить отримувати збільшений вихід борошна та харчових висівок при скороченні технологічного процесу та підвищенні харчової цінності продуктів.

В ході досліджень розроблено структуру переробки голозерного вівса в борошно, що передбачає очищення зерна від домішок, шліфування, сортування продуктів шліфування, воднотеплову обробку, здрібнювання та сортування продуктів здрібнювання.

Очищення зерна голозерного вівса від домішок здійснюється у скальператорі, ситоповітряному сепараторі, магнітному сепараторі, каменевідбірнику, круп'яному розсійнику, трієрах та падді-машині. Очищення зерна голозерного вівса за такою структурою дозволить проводити найбільш повне вилучення домішок із зерна, що дозволить підвищити ефективність наступних етапів переробки та за забезпечить стабільну якість готової продукції.

Переробка голозерного вівса в борошно здійснюється без застосування етапу воднотеплової обробки перед шліфуванням, що дозволить більш ефективно здійснювати зняття поверхневих шарів зерна при скороченому етапі шліфування, який проводять за принципом інтенсивного стирання оболонок у шліфувальних машинах типу ЗШН. Шліфування зерна за таким принципом дозволить проводити вилучення 3 поверхні зерна шкідливих речовин які потенційно можуть потрапити в голозерне зерно в полі, при транспортуванні або зберіганні та вилучати складно засвоювані оболонки та волоски опушення (тріхоми) які переважно складаються 3 не засвоюваної клітковини. Разом $з$ цим $з$ поверхні зерна вилучаються шкідливі мікроорганізми, що забезпечує зменшення мікробіологічного обсіменіння.
Суміш продуктів шліфування направляють у круп'яні розсійники на сортування основною метою якого є розділення продуктів шліфування на три фракції - ціле ядро, борошенце та подрібнене ядро. Фракцію цілого ядра контролюють шляхом послідовного пропуску крізь системи повітряних сепараторів та на вміст металомагнітних домішок у магнітних сепараторах.

Після чого іiї спрямовують на етап воднотеплової обробки який в залежності від подальшого його використання проводять методом гарячого кондиціювання. Як відомо обробка зернових культур насиченою парою дозволяє майже повністю зменшити мікробіологічне обсіменіння на поверхні зерна. Окрім цього при пропарюванні в зерні відбувається зменшення активності ліполітичних ферментів ліпази та ліпоксигенази в декілька разів. Тому метою даного етапу, при виробництві борошна $є$ інактивація ліполітичних ферментів у вівсяному ядрі яка дозволить зменшити окислювальні процеси та підвищить термін його зберігання, а також проведення його часткової стерилізації (зменшення мікробіологічного обсіменіння), що також дозволить збільшити термін зберігання продукту та в подальшому використовувати отримані при здрібнюванні висівки на харчові потреби.

Після пропарювання ядро підсушують та направляють на здрібнювання яке проводять у вальцьових верстатах на двох драних системах. Враховуючи особливості хімічного складу вівса (високий вміст жиру, наявність слизистих речовин) після кожної драної системи передбачається додаткове здрібнювання продуктів в ентолейторі.

Сортування продуктів здрібнювання проводять після кожної системи. Для сортування використовують круп'яні розсійники. Борошно вівсяне відбирають проходом сит № 067 на кожній сортувальній системі. Схід 3 цього сита після другої драної системи являє собою вівсяні висівки, які можна використовувати як харчовий продукт.

В ході досліджень розроблено структуру та обгрунтовано використання основних етапів технологічного процесу переробки зерна голозерного вівса в борошно, що передбачає отримання вівсяних харчових висівок. Технологічний процес має скорочену структуру, у ньому відсутні етапи лущення, сортування продуктів лущення, круповідділення які традиційно застосовуються на вітчизняних заводах при виробництві вівсяного борошна. Отримана структура дозволяє зменшити енерговитрати, розширити асортимент існуючих вівсяних круп'яних продуктів, підвищити вихід готової продукції та за рахунок використання голозерного вівса. Розроблена технологія дозволяє покращити харчову цінність продукції.

\section{ЛІТЕРАТУРА}

1. Правила організачії і ведення технологічного прочесу на круп'яних заводах. - K., 1998. - 164 с.

2. Шутенко Є.I. Технологія круп'яного виробниџтва: навч. посібник / Є.І. Шутенко, С.М. Сои.- К.: Освіта Украӥни, 2010. - 272 с.

3. Кустов І.О. Особливості технологічних властивостей та хімічного складу голозерного вівса сорту «Саломон/ I.О. Кустов, С.М. Соч // Харчова наука і технологія. - 2015. -№ 2 (31). - C. $103-108$.

4. Sots, S. Some Features of chemical composition of Ukrainian naked oats variety «Salomon» / S. Sots, I. Kustov, Y. Kulyna // Zbior raportow naukowych. Wykonane na materialach Miedzynarodowej Naukowo-Praktycznej Konferencji «Aktualne naukowe problemy. Rozpatrzenie, decyzja, praktyka.». 29.06.2014 - 30.06.2014 roku Wrocław. - Warszawa: Wydawca: Sp. z o.o. «Diamond trading tour», 2014. - S. $28-31$ 
5. Schnitzenbaumer, B. Implementation of commercial oat and sorghum flours in brewing / B. Schnitzenbaumer, J. Kaspar, J. Titze, et al. // European Food Research and Technology. - 2014. - vol. 238, № 3. - P. $515-525$.

6. Biliaderis, C.G. Functional food carbohydrates / C. G. Biliaderis, M.S. Izydorczyk. - CRC Press Taylor \& Francis Group, 2007. - 570 p.

7. Guan, X. Some functional properties of oat bran protein concentrate modified by trypsin /X. Guan, H. Yao, Z.Chen, L. Shan, M. Zhang // Food Chemistry. - 2007. - № 101 (1). - P. $163-170$.

8. Seppo, K. A method for preparing an oat product and a foodstuff enriched in the content of $\beta$-glucan / K. Sepро, еt al. // [Електронний pecypc]. - режим достуny: http://www.google.tl/patents/WO2001026479A1?cl=en

9. Størsrud, S. Gluten contamination in oat products and products naturally free from gluten / S. Størsrud, I.M. Yman, R.A. Lenner // European Food Research and Technology. -2003. - vol. 217, № 6. - P. $481-485$.

10. Rieder, A. Effect of barley and oat flour types and sourdoughs on dough rheology and bread quality of composite wheat bread / A. Rieder, A.K. Holtekjølen, S. Sahlstrøm, A. Moldestad // Journal of Cereal Science. - 2012. - vol. 55, № 1. - P. 44 - 52.

11. Gambus, $H$. The application of residual oats flour in bread production in order to improve its quality and biological value of protein $/$ H. Gambuś, M. Gibiński, D. Pastuszka, et al. // Acta Sci. Pol. - 2011. - vol. 10, № 3. - P. $313-325$.

12. Londono, D.M. Effect of kilning and milling on the dough-making properties of oat flour / D.M. Londono, M.J. Smulders, R.G. Visser, L. et al. // LWT-Food Science and Technology. - 2015. - № 2. - P. 690-695.

13. Shrestha, R. Oat flour incorporated cakes as functional food for growing children / R. Shrestha, P. Awasthi, N. Tiwari // Pantnagar Journal of Research. 2013. - vol. 11, № 3. - P. $449-452$.

14. Tiwari, U. Simulation of the factors affecting $\beta$-glucan levels during the cultivation of oats / U. Tiwari, E. Cummins // Journal of Cereal Science. -2009 . - vol. 50, № 2. - P. $175-183$.

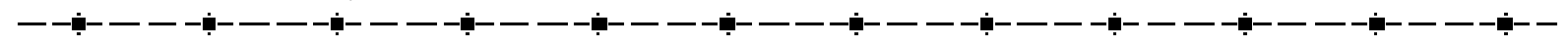

\title{
S. SOTS, PhD., Associate Professor, V. GULAVSKIJ, PhD., I. KUSTOV, PhD., Sc. Science \\ Odessa National Academy of Food Technologies, Odessa \\ FLOUR AND BRAN NEW PRODUCTS FROM NAKED OATS
}

\begin{abstract}
Analysis of existing traditional technologies in Ukraine of grains and legumes processing into groats and groats products shows that the vast majority of existing technology was developed 20-30 years ago and involves the use of a large number of systems and operations especially hulling and pearling when implementing that require the use of machines such as ZSHN which provides significant energy costs of process. At that range of produced groat products are more stable and include grinded groats, grounded groats, flacks and flour. In recent years in modern countries is the transition to the new reduced and more energy efficient technologies of processing cereals into groats and groats products this is also accompanied the introduction of new highly productive varieties of grain crops. The special place is occupied with hulless forms of traditional crops - oats and barley. Based on these raw materials is expanding the product range, increase finished product production, increasing its nutritional value. In our country, national breeders also received highly productive varieties of conventional grain crops but must pay attention to the fact that, for example, new varieties of wheat by an overwhelming measure on anatomical and morphological structure are similar to conventional wheat and their processing do not require significant restructuring of technological process but such cultures as naked oats or hulless barley process according to existing regimes and structures is difficult this leads to underutilization of potential of raw materials and eliminates all its advantages over conventional crops. Given this urgent problem for the national groat production are developments of new expansion of the existing product range and increasing its nutritional value energy efficient technologies. In Odessa National Academy of Food Technologies at the Department of grain processing technology conducts researches which aim to develop of scientifically based technologies of processing new kinds of cereal crops and their implementation in the national groat production. This article describes the structure and main stages of processing naked oats in groats products. Given the main differences between used of naked and conventional oats forms for processing groats products. Possibilities of use naked oats as raw material for expanding range of oats products were conducted. Technological process of processing naked oats into boiling groats, not boiling groats, flakes and flour characterized by the reduced structure of technological process, products in comparison with classical have increased yield and quality.
\end{abstract}

Keywords: oats groat, water-heat treatment, grain cleaning, boiling, flaked products, oats flour, reduced structure of technological process, increase nutritional value.

\section{REFERENCES:}

1. Rules of organization and management process in groat plants. - K., 1998. $-164 \mathrm{p}$.

2. Shutenko E.I. Groats production technology: teach. manual / E.I. Shutenko, S.M. Sots.- K.: Osvita Ukrainy, 2010. - 272 p.

3. Kustov I.O. Features of technological properties and chemical composition od naked oat variety "Salomon» / I.O. Kustov, S.M. Sots // Food Science and Technology. -2015. - № 2 (31). - P. $103-108$.

4. Sots, S. Some Features of chemical composition of Ukrainian naked oats variety «Salomon» / S. Sots, I. Kustov, Y. Kulyna // Zbior raportow naukowych. Wykonane na materiałach Miedzynarodowej Naukowo-Praktycznej Konferencji «Aktualne naukowe problemy. Rozpatrzenie, decyzja, praktyka.». 29.06.2014 - 30.06.2014 roku Wrockaw. - Warszawa: Wydawca: Sp. z o.o. «Diamond trading tour», 2014. - S. $28-31$.

5. Schnitzenbaumer, B. Implementation of commercial oat and sorghum flours in brewing / B. Schnitzenbaumer, J. Kaspar, J. Titze, et al. // European Food Research and Technology. - 2014. - vol. 238, № 3. - P. $515-525$.

6. Biliaderis, C.G. Functional food carbohydrates / C. G. Biliaderis, M.S. Izydorczyk. - CRC Press Taylor \& Francis Group, 2007. - 570 p.

7. Guan, X. Some functional properties of oat bran protein concentrate modified by trypsin /X. Guan, H. Yao, Z.Chen, L. Shan, M. Zhang // Food Chemistry. - 2007. - № 101 (1). - P. 163 - 170.

8. Seppo, K. A method for preparing an oat product and a foodstuff enriched in the content of $\beta$-glucan / K. Sерро, еt al. // [Електронний ресурс]. - режим доступу:

9. http://www.google.tl/patents/WO2001026479A1?cl=en

10. Størsrud, S. Gluten contamination in oat products and products naturally free from gluten / S. Størsrud, I.M. Yman, R.A. Lenner // European Food Research and Technology. -2003. - vol. 217, № 6. - P. 481-485.

11. Rieder, A. Effect of barley and oat flour types and sourdoughs on dough rheology and bread quality of composite wheat bread / A. Rieder, A.K. Holtekjølen, S. Sahlstrøm, A. Moldestad // Journal of Cereal Science. - 2012. - vol. 55, № 1. - P. 44 - 52 .

12. Gambus, $H$. The application of residual oats flour in bread production in order to improve its quality and biological value of protein $/$ H. Gambuś, M. Gibinski, D. Pastuszka, et al. // Acta Sci. Pol. - 2011. - vol. 10, № 3. - P. $313-325$. 
13. Londono, D.M. Effect of kilning and milling on the dough-making properties of oat flour / D.M. Londono, M.J. Smulders, R.G. Visser, L. et al. // LWT-Food Science and Technology. - 2015. - № 2. - P. 690-695.

14. Shrestha, R. Oat flour incorporated cakes as functional food for growing children / R. Shrestha, P. Awasthi, N. Tiwari // Pantnagar Journal of Research. 2013. - vol. 11, № 3. - P. $449-452$.

15. Tiwari, U. Simulation of the factors affecting $\beta$-glucan levels during the cultivation of oats / U. Tiwari, E. Cummins // Journal of Cereal Science. -2009. - vol. 50, № 2. - P. $175-183$.

Надійшла 23.05.2016. До друку 27.05.2016

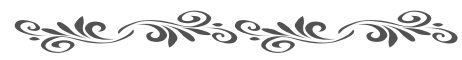

Б.В. СГОРОВ, д-р техн. наук, професор, О.С. ВОСЦЬКА, канд. техн. наук, доцент,

\title{
ОСОБЛИВОСТІ ПЕРЕРОБКИ ЯБЛУЧНИХ ВИЧАВКТВ ПРИ ВИРОБНИЦТВІ КОМБІКОРМІВ АЛЯ КОНЕЙ
}

\begin{abstract}
Анотація
У статті розглянута загальна ситуація розвитку конярства в Україні та проблеми зниження динаміки поголів'я коней. Також розглянуто розподіл поголів'я коней по господарствам різних форм власності та структура виробнищтва комбікормів для сільськогосподарських тварин, у тому числі для коней.

Зроблено аналіз виробнищтва яблук в Украӥні, з якого видно тенденцію зростання виробництва. Переробка яблук полягає в отриманні основної продукції, а також в отриманні побічної продукції.

Розглянута можсливість використання яблучних вичавків як компонента комбікормів. У лабораторних умовах досліджені фізичні властивості, хімічний склад та мікробіологічні показники свіжси яблучних вичавків. Яблучні вичавки багаті безазотистими екстрактивними речовинами, а також незамінними амінокислотами, вітамінами і мінеральними елементами. Яблучні вичавки не стійкі при зберіганні та швидко псуються, тому досліджено динаміку мікрофлори та терміни зберігання свіжих яблучних вичавків.

Обтрунтовано вибір зерна ячменю для виробництва кормової добавки. Наведена поетапна схема виробництва кормової добавки шляхом екструдування суміші подрібненого зерна ячменю та подрібнених яблучних вичавків. На основі експериментальних досліджень обтрунтовано співвідночення компонентів екструдованої кормової добавки (ЕКД). Для визначення оптимального співвідношення компонентів ЕКД досліджено вплив введення яблучних вичавків на ефективність процесу екструдування за якісними та енергосиловими показниками, а саме за коефіцієнтом розширення екструдату та питомими витратами електроенергї. Досліджено вплив екструдування на зміну фізичних властивостей ЕКД. Також досліджено зміни хімічного складу ЕКД. У зразках кормової добавки визначали ступінь набухання, яка характеризує ефективність засвоєння поживних речовин організмом тварин.

Досліджено вплив екструдування на зміну кількісного і якісного складу мікрофлори в зерні ячменю, свіжих яблучних вичавок і кормової добавки до і після екструдування. Також досліджено динаміку розвитку мікрофлори ЕКд протягом 6 місяиів зберігання у нерегульованих умовах.
\end{abstract}

Ключові слова: конярство, яблучні вичавки, кормова добавка, екструдування, комбікорм-конщентрат, рецепт.

Незважаючи на різноманітність напрямків, загальна динаміка поголів'я коней в Україні за останні шість років поступово знижується (рис.1). Це пов'язано зі скороченням земельних угідь, проблемами 3 реалізацією коней, відсутністю нормального державного фінансування конярства. Тому основна частина поголів'я коней знаходиться в приватній власності (рис. 2) [1].

Серед різних видів сільськогосподарських тварин найбільша кількість комбікормів у світі виробля-

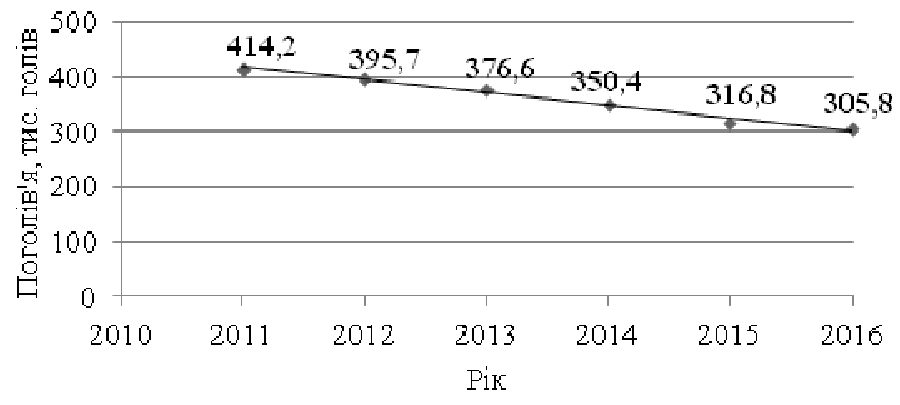

Рис. 1 - Загальна динаміка поголів'я коней в Украӥні, тис. голів [1]

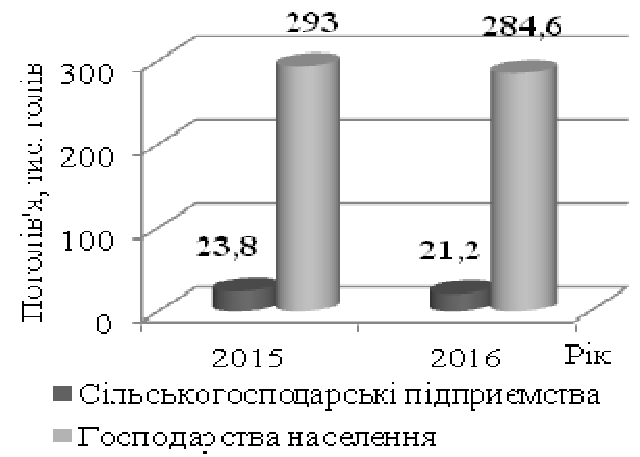

Рис. 2 - Перерозподіл поголів'я коней по господдарствах різних форм власності (тис. гол.) [1]

ється для сільськогосподарської птиці - 45 \%, частка комбікормів для коней становить лише $1 \%$ (рис. 3) [2]. Низький відсоток виробництва комбікормів для коней пов'язаний з нестабільним попитом і складністю розведення коней.

Аналіз ринку комбікормів для коней свідчить про те, що на ринку істотно переважають комбікорми імпортного виробництва, основні країни-виробники 3 